\title{
Evaluation of overweight and obesity in Helicopter Emergency Medical Service (HEMS) worker
}

\author{
Robert Gałązkowski', Agata Gaździńska², Marcin Kopka², Robert Drozdowski², Mariusz Wyleżoł² \\ ${ }^{1}$ Department of Emergency Medical Services, Medical University, Warsaw, Poland \\ ${ }^{2}$ Military Institute of Aviation Medicine, Warsaw, Poland
}

Gałązkowski R, Gaździńska A, Kopka M, Drozdowski R, Wyleżoł M. Evaluation of overweight and obesity in Helicopter Emergency Medical Service (HEMS) worker. Ann Agric Environ Med. 2015; 22(3): 542-545. doi: 10.5604/12321966.1167731

\begin{abstract}
Introduction. Obesity now affects people from all walks of life, including those who work in the field of medical aid provision on a daily basis. So far, there has been no research assessing the nutrition status of Helicopter Emergency Medical Service (HEMS) crews.

Objectives. To evaluate the degree to which overweight and obesity prevail among Helicopter Emergency Medical Service Air Ambulances (HEMS LPR) crew members, and determine the overall excess body fat and fatty tissue distribution in the subjects.

Material and methods. In order to evaluate the prevalence of overweight and obesity in HEMS crew members, the following anthropometric measurements were used: height, body mass, waist and hip circumferences. Assessment of their nutritional status was made by using some generally used indicators, i.e. calculating the subjects' BMI, WHR and WHtR.

Results. Pilots were older than the paramedics in a statistically significant way. On the basis of using the BMI indicator, it was shown that only $36 \%$ of HEMS crew members had normal body weight. Analysis of the percentage of body fat determined that $61.5 \%$ of the paramedics and $39.4 \%$ of the pilots had normal weight. $26.2 \%$ paramedics and $28.8 \%$ pilots were diagnosed as overweight. Obesity characterised $12.3 \%$ of paramedics and $31.8 \%$ of pilots. The above were statistically significant differences $(p=0.0117)$. Waist circumference exceeded $102 \mathrm{~cm}$ in $25.9 \%$ of the subjects and WHR $>1$ characterised $20.6 \%$ of those examined.

Conclusions. Analysis of the results obtained revealed that an alarmingly high percentage of crew members suffer from excessive body mass and fat, particularly in the group of pilots. Immediate action should be taken in order to reduce the body mass and introduce preventive measures among the subjects.
\end{abstract}

\section{Key words}

HEMS, overweight, obesity, BMI, WHR

\section{INTRODUCTION}

All over the world, including Poland, obesity has become one of the major social and personal problems [1]. In spite of the progress made in its treatment, obesity now occurs three times as frequently as twenty years ago. Most epidemiological surveys show that over $50 \%$ of the population suffers from overweight or obesity $[1,2,3]$. Obesity is a pathological condition in which body fat exceeds the norm to the extent it has an adverse effect on the human organism, leading to increased health risks and mortality [4].

There are a few methods for assessing correct body mass. The one that is most frequently used is BMI (Body Mass Index) [5], which is determined on the basis of the individual's body mass and height using the formula BMI = body mass $(\mathrm{kg}) /$ height $(\mathrm{m})^{2}$. The World Health Organization regards a BMI of $25-29.9 \mathrm{~kg} / \mathrm{m}^{2}$ as overweight and a BMI $>30 \mathrm{~kg} / \mathrm{m}^{2}$ as obesity. This is broken down into three classes: I class (BMI 30.0-34.9), II class (BMI 35-39.9) and III class (BMI >40) [1]. The latter class of obesity is also sometimes referred to as extreme or morbid [5].

Address for correspondence: Robert Gałązkowski, Department of Emergency Medical Services, Medical University, Warsaw, Poland

E-mail: j.sochacka@lpr.com.pl

Received: 27 December 2013; accepted: 09 April 2014
BMI does not specify either the distribution or the amount of body fat in the organism. Therefore, use is also made of the WHR indicator, which is the ratio of the circumference of the waist to that of the hips (waist to hip circumference ratio). The waist circumference is measured at the midpoint between the lower margin of the last palpable rib and the top of the iliac crest, and the hip circumference at the level of the greater trochaners. [6]. On the basis of this ratio, two types of obesity are identified: abdominal (visceral) and lower-body/ peripheral (gluteal-femoral). Abdominal obesity is diagnosed when WHR is $\geq 0.8$ in women and $\geq 1.0$ in men [4]. Lower body/peripheral obesity is diagnosed when WHR is WHR $<0.8$ in women and $<1.0$ in men [4].

According to some researchers, the circumference of the waist itself is an easy indication of overall body fat. It has been shown that it has a close correlation with the risk of heart disease, hypertension and diabetes $[7,8,9]$. Men whose waist exceeds $102 \mathrm{~cm}$ have an increased risk of metabolic complications in comparison to those with a waist circumference measuring $94 \mathrm{~cm}$ [10].

Obesity affects people from all walks of life, including those who provide medical aid to others on a daily basis. The Polish Air Ambulance works in the field of providing emergency and sanitary services in the country's health service. It works now from seventeen permanent bases. The crew of the Helicopter Emergency 
Medical Service consists of: a pilot, paramedic/nurse and doctor.

Up to now there has been no assessment of the nutritional status of HEMS crews.

\section{OJECTIVES}

The aim of the work was to evaluate the degree to which overweight and obesity prevail among the members of the HEMS Air Ambulances and to specify overall body fat and the distribution of body fat, measured by means of selected somatic and anthropometric indicators.

\section{MATERIALS AND METHOD}

Towards the end of 2012, all HEMS pilots and paramedics aged 27-59 were examined ( 66 pilots, 65 paramedics). Most of them were men, with women accounting for only $3.8 \%$ (exclusively paramedics). None of the respondents had taken earlier action to improve their health behaviours to reduce body weight. The following anthropometric measurements were evaluated in order to check if they suffered from overweight or obesity: height, body mass, waist and hip circumference. Generally used nutrition status indicators were calculated on the basis of the data obtained:

- $\mathrm{BMI}=$ body mass $(\mathrm{kg}) /$ height $\left(\mathrm{m}^{2}\right)$, which were interpreted on the basis of the WHO classification [1];

- WHR [waist circumference $(\mathrm{cm}) /$ hip circumference $(\mathrm{cm})]$;

- WHtR [waist circumference $(\mathrm{cm}) /$ height $(\mathrm{cm})$ ];

The parameters of electrical impedance indicating the amount of total body fat in the organism were measured using an impedance analyser (Tanita SC-330).

Statistical analyses were made using $\mathrm{R}$ software (2.15.1 version). Comparative analyses between the groups were measured using chi ${ }^{2}$ and Mann-Whitney $U$ tests. Statistical significance was assumed at the level of $\mathrm{p}<0.05$.

\section{RESULTS}

The average age of those examined was $42.73 \pm 9.58$. Pilots were older than paramedics in a statistically significant way (49.12 \pm 7.52 vs. $36.23 \pm 6.64$ years; $p<0.0001)$. Moreover, there were statistically significant differences between paramedics and pilots in all the parameters tested, apart from height, e.g.: body mass $83.10 \pm 11.81$ vs. $89.20 \pm 16.75 \mathrm{~kg}(\mathrm{p}=0.0478), B M I$ $25.84 \pm 3.17$ vs. $28.27 \pm 4.95 \mathrm{~kg} / \mathrm{m}^{2}(\mathrm{p}=0.0023)$, the percentage of body fat $21.38 \pm \mathrm{c} 5.81$ vs. $24.88 \pm 6.18 \%(\mathrm{p}=0.0012)$, waist circumference $96.95 \pm 11.38$ vs. $99.55 \pm 12.86 \mathrm{~cm}(\mathrm{p}=0.02)$ (Fig. 1).

On the basis of BMI, it was shown that only $36 \%$ of HEMS crews had normal body mass. Over $20 \%$ were diagnosed with obesity, while $3 \%$ with extreme obesity. (BMI $>>40$ ). The results are shown in Figure 1.

Moreover, an analysis was made of the degree of overweight and obesity depending on the job being performed by the subjects. It was found that $46.2 \%$ of the paramedics and $25.8 \%$ of the pilots had correct body mass. Those with overweight accounted for $43 \%$ paramedics and a similar number of pilots (43.9\%). Obese crew members accounted for $10.8 \%$

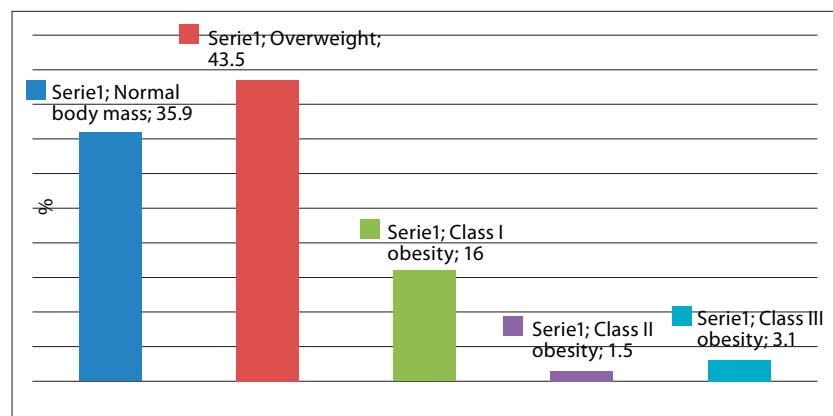

Figure 1. Assessment of overweight and obesity among all subjects on the basis of BMI (acc. to WHO classification, 1)

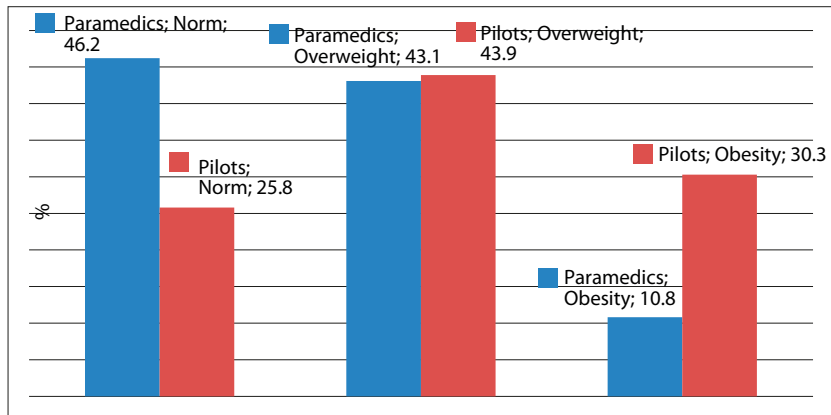

Figure 2. Nutritional state based on BMI with a breakdown taking into account pilots and paramedics (acc. to WHO classification, 1)

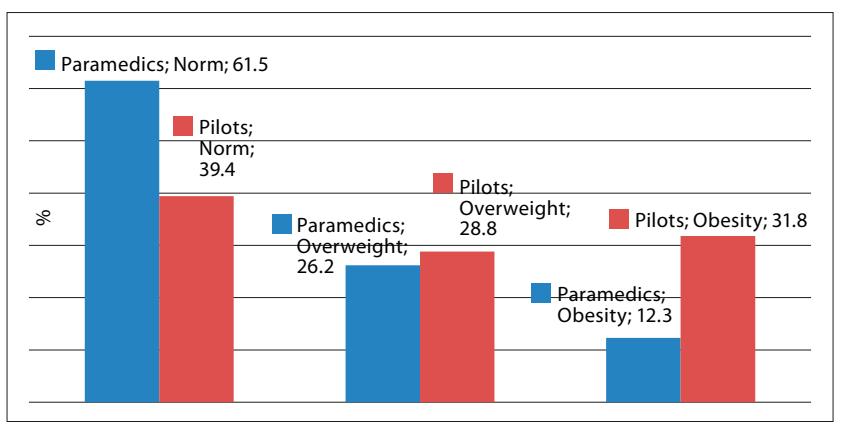

Figure 3. Nutritional status according to percentage of body fat in the organism

of the total number of paramedics and $30.3 \%$ of the pilots (Figure 2).

The percentage analysis of body fat in the subjects showed that $61.5 \%$ of the paramedics examined and $39.4 \%$ of the pilots obtained normal results. $26.2 \%$ paramedics and $28.8 \%$ pilots were overweight, while $12.3 \%$ paramedics and $31.8 \%$ pilots obese. The differences were statistically significant $(\mathrm{p}=0.0117)$.

The WHR and waist circumference can be significant indicators of cardiovascular risk and type II diabetes. Among those examined, waist circumference was over $102 \mathrm{~cm}$ in $25.9 \%$, and in $20.6 \%$ the WHR exceeded 1 , which indicates excessive body fat accumulation in the abdominal area.

The WHtR makes it possible to assess the risk of dietrelated diseases, which can be prevented or minimised by making appropriate dietary and lifestyle changes. The result of WHtR $\geq 0.56$ (29\% of those examined) signals the risk of type II diabetes, and the result of $\geq 0.59$ (17.6\% of those examined) indicates a risk of hypertension [11]. 
Table 1. Anthropometric measurements of the subjects with a breakdown by job performed

\begin{tabular}{|c|c|c|c|c|c|c|c|}
\hline \multirow{2}{*}{ Variables } & \multicolumn{2}{|c|}{ Subjects overall } & \multicolumn{2}{|c|}{ Paramedics } & \multicolumn{2}{|r|}{ Pilots } & \multirow[b]{2}{*}{$\mathrm{p}$} \\
\hline & $\mathrm{N}$ & $\mathrm{X} \pm \mathrm{SD}$ & $\mathrm{N}$ & $\mathrm{X} \pm \mathrm{SD}$ & $\mathrm{N}$ & $\mathrm{X} \pm \mathrm{SD}$ & \\
\hline Age [years] & 131 & $42.73 \pm 9.58$ & 65 & $36.23 \pm 6.64$ & 66 & $49.12 \pm 7.52$ & $<0.0001$ \\
\hline Height [cm] & 131 & $178.36 \pm 5.86$ & 65 & $179.23 \pm 6.09$ & 66 & $177.50 \pm 5.53$ & 0.0712 \\
\hline Weight [kg] & 131 & $86.17 \pm 14.78$ & 65 & $83.10 \pm 11.81$ & 66 & $89.20 \pm 16.75$ & 0.0478 \\
\hline Body fat [\%] & 131 & $2.14 \pm 6.23$ & 65 & $21.38 \pm 5.81$ & 66 & $24.88 \pm 6.18$ & 0.0012 \\
\hline BMI $\left[\mathrm{kg} / \mathrm{m}^{2}\right]$ & 131 & $27.07 \pm 4.32$ & 65 & $25.84 \pm 3.17$ & 66 & $28.27 \pm 4.95$ & 0.0023 \\
\hline WHR & 131 & $0.96 \pm 0.06$ & 65 & $0.94 \pm 0.05$ & 66 & $0.97 \pm 0.07$ & 0.0184 \\
\hline Watr & 131 & $0.54 \pm 0.06$ & 65 & $0.53 \pm 0.05$ & 66 & $0.56 \pm 0.07$ & 0.0036 \\
\hline $\begin{array}{l}\text { Waist } \\
\text { circum- } \\
\text { ference } \\
{[\mathrm{cm}]}\end{array}$ & 131 & $96.95 \pm 11.38$ & 65 & $64.3 \pm 9.01$ & 66 & $99.55 \pm 12.86$ & 0.0212 \\
\hline
\end{tabular}

$\mathrm{N}$-number of subjects; $\mathrm{X}$-mean value; $\mathrm{SD}$ - standard deviation; $\mathrm{p}$ - statistical significance value BMI - Body Mass Index; WHR - Waist to Hip Ratio; WHtR - Waist to Height Ratio

\section{DISCUSSION}

Performing the tasks that are required of HEMS crews makes it important that they should be healthy and extremely fit, the precondition of which is maintaining correct body mass. It has been proved that people with overweight are less fit than those with normal weight [12]. Moreover, it has been observed that there is an inversely proportional dependence between physical fitness, the BMI indicator and age [13].

On the basis of analysing BMI, it was shown that over $40 \%$ of HEMS crew members were overweight, while over $20 \%$ obese, with $3 \%$ of the latter suffering from extreme obesity defined as BMI $>40$. When analysing the particular groups, it was determined that overweight paramedics accounted for $43 \%$ of this profession among the crews and $43.9 \%$ of the pilots, while obesity affected $10.8 \%$ of the paramedics and $30.3 \%$ of the pilots.

Examinations of the nutritional status of Polish military flying personnel in the Polish army showed that overweight prevails among over $50 \%$ of those examined, both in the under 30 year-old group, as well as in those over 30, while obesity was diagnosed in $10.5 \%$ of those under 30 years old and in $18.9 \%$ of the older subjects [14]. It must be noted, however, that the subjects were older people, and the problem of overweight and obesity increases with age, which has been proved by numerous studies $[15,16,17]$.

The results of examining the nutritional status of the military medical flying personnel obtained by Kłos et al. showed that $53.3 \%$ of the doctors and $61.9 \%$ of the paramedics were overweight, while obesity was diagnosed in $20 \%$ of the doctors and $16.7 \%$ of the paramedics [18]. These values were higher than those obtained when evaluating the degree of overweight and obesity among the paramedics working on HEMS crews.

Although BMI is a useful tool to determine overall body fat, it does not reflect non-fat body mass, which is a disadvantage of this indicator, because it does not reflect the distribution of fatty tissue in the body, and therefore does not precisely assess the risk connected with overweight. Diagnosing overweight on the basis of BMI only is burdened with the risk that such people as, for example, muscular athletes, who have little fat, can fall into the overweight category. Another risk is that people with excessive body fat may not be diagnosed as obese, and in spite of the excessively high percentage of body fat in their organism, their BMI may fall in the under $30 \mathrm{~kg} / \mathrm{m}^{2}$ class [19].

Bearing in mind that obesity is defined as the pathological accumulation of excess body fat, the main assessment criterion should therefore not be body mass but the percentage of body fat in relation to total weight. The average percentage of body fat in the European population is $15 \%-18 \%$ in men and $22-25 \%$ in women, while the optimal values, i.e. those that do not carry the risk for complications, are in the range of up to $5 \%$ and $12 \%$, respectively [20]. If body fat exceeds $20 \%$ in men and $30 \%$ in women, they are diagnosed as obese [21].

Body fat was also evaluated in the study of the nutritional status of HEMS crews. Judging on the basis of generally accepted norms, the normal amount was diagnosed in $61.5 \%$ of the paramedics examined and $39.4 \%$ of the pilots. Overweight was found in $26.2 \%$ of paramedics and $28.8 \%$ of pilots. Obesity characterised $12.3 \%$ of the paramedics and $31.8 \%$ of the pilots. Body fat percentage significantly increased with age. Research conducted among military pilots also showed that body composition is adversely affected by weight [16].

In both groups, the paramedics as well as the pilots, a lower percentage of those with overweight and obesity were found than shown by the results obtained by applying BMI.

For many years, epidemiological data have shown that in Western societies the most frequent causes of death are cardiovascular diseases, the development of which is mainly brought on by excessive body fat. The high metabolic activity of fat tissue is one of the factors increasing the risk of oxidative stress which, in connection with lipid disorders and chronic inflammation, constitutes the basic mechanism of the initiation of atherogenesis [22, 23]. Moreover, the inflammation process, which is connected with the increase of metabolic activity of fat cells, plays a role in insulin resistance, which is one of the main mechanisms in the development of the metabolic syndrome $[22,23]$. Additionally, some authors suggests that obesity may be one of the risk factors for dementia [24].

One of the basic criteria of diagnosing metabolic syndrome is abdominal obesity. Analysis of indicators based on measuring the waist and hips showed that with age the risk of the overall accumulation of body fat in men is not only higher, but most importantly, there is an increase in the central belt around the stomach, characteristic of abdominal or visceral fat. Similar results were shown by the research of Socha et al. [15]. The authors explain the rising values of WHR and waist circumference indicators by the existence of a process of body fat redistribution in male organisms in such a way that the trunk of the body accumulates more fat in relation to the decreasing fat of the extremities.

Increasing body mass leads to deterioration of the quality of life, shortens life expectancy, and undoubtedly worsens the quality of one's work. Fogelholm et al. [25] maintain that besides suffering from a lower efficiency of the cardiovascular system, people with a higher percentage of body fat also suffer from the impairment of motor skills, which makes it more difficult for them to perform their tasks at work. This problem is particularly significant in relation to the Helicopter Emergency Medical Service, where the crew must react quickly and be on permanent alert to perform their tasks. 


\section{CONCLUSIONS}

1. Analysis of the results obtained shows an alarmingly high percentage of subjects with excessive body mass and body fat, particularly in the group of pilots.

2. Immediate action should be taken to reduce the body mass among the subjects in the group examined and introduce preventive measures to decrease the number of people with excessive body mass.

\section{REFERENCES}

1. WHO. Obesity: preventing and managing the global epidemic: report of a WHO consultation (ISSN 05 12-3054): WHO; Geneva, Switzerland; 1999. WHO Tech Rep Ser., 894.

2. Kottke TE, Wu LA, Hoffman RS. Economic and psychological implications of the obesity epidemic. Mayo. Clin. Proc. 2003; 78: 92-94.

3. Flegal KM, Carroll MD, Ogden CL, et al. Prevalence and trends in obesity among US adults 1999-2000. JAMA 2002; 288: 1723-1727.

4. Szostak WB, Białkowska M, Cybulska B i wsp. Leczenie otyłości u ludzi dorosłych. Rekomendacje Narodowego Programu Profilaktyki Cholesterolowej. Medycyna po Dyplomie 2000: 163-180 (in Polish).

5. Pi-Sunyer FX. Obesity: criteria and classification. Proc Nutr Soc 2000; 59: 505-509.

6. Deurenberg P, Weststrate J, Seidell J. Body Mass Index as a measure of body fatness: ag.e - and sex - specific prediction formulas. Br J Nutr, 1991; 65: 105-114.

7. Farin HMF, Abbasi F, Reaven GM. Comparison of body mass index versus waist circumference with the metabolic changes that increase the risk of cardiovascular disease in insulin-resistant individuals. Am J Cardiol. 2006; 98: 1053-1056.

8. Janssen I, Katzmarzyk PT, Ross R. Waist circumference and not body mass index explains obesity-related health risk. Am J Clin Nutr. 2004; 79: $379-384$

9. Juonala M, Magnussen CG, Berenson GS, Venn A, Burns TL, Sabin MA, et al. Childhood adiposity, adult adiposity, and cardiovascular risk factors. N Engl J Med 2011, 365(20): 1876-1885.

10. Diet, nutrition and the prevention of chronic diseases. WHO Technical report Series, 2003; 916: 1-149.
11. Mansour AA, Al-Jazairi MI. Cut-off Values for Anthropometric Variables That Confer Increased Risk of Type 2 Diabetes Mellitus and Hypertension in Iraq. Archiv Med Res. 2007, 38: 253-258.

12. Kłossowski M, Stelęgowski A. Ocena związku między masą i składem ciała a sprawnością fizyczną podchorążych Wyższej Szkoły Oficerskiej Sił Powietrznych, Pol Przegl Med Lotn. 2004; 1, (10): 35-42 (in Polish).

13. Lavie CJ, Kuruvanka T, Milani RV, Prasad A, Ventura HO. Exercise capacity in adult African-Americans referred for exercise stress testing: Is fitness affected by race? Chest. 2004; 126: 1926-1968.

14. Kłos A, Bertrandt J, Kłos K. Występowanie nadwagi i otyłości wśród wojskowego personelu latającego. Pol Przegl Med Lotn. 2008, 4: 337-343 (in Polish).

15. Socha M, Bolanowski M, Jonak W, Lewandowski Z. Otłuszczenie ogólne i dystrybucja tkanki tłuszczowej u mężczyzn w starszym wieku. Endokrynologia Otyłość i Zaburzenia Przemiany Materii 2007; 3(4): 73-78 (in Polish).

16. Kłosowski M, Dębska A, Stelęgowski A. Ocena problemu nadwagi u podchorążych i pilotów wojskowych w wieku 18-45 lat. Nowiny Lekarskie 2008, 77,3, 218-222 (in Polish).

17. Chapman IM. Obesity In old age. Front Horm Res. 2008; 36: 97-106.

18. Kłos A, Bertrandt J. Występowanie nadwagi i otyłości oraz ocena stanu odżywienia mineralnego wojskowego medycznego personelu latającego. Lek Wojsk. 2011, 21: 93-97 (in Polish).

19. Ganz ML. The economic evaluation of obesity interventions: its time has come. Obes Res. 2003; 11: 1275-1277.

20. Quinn E. The most common methods to measure body composition and body fat. Guide Health Sports Medicine 2011.

21. Prentice AM, Jebb SA. Beyond body mass index. Obes Rev. 2001; 2: 141-147.

22. Sowers JR. Obesity as a cardiovascular risk factor. Am J Med. 2003; 115(Suppl 8A): 37-41

23. Reaven G, Abbasi F, McLaughlin T. Obesity, insulin resistance, and cardiovascular disease. Recent Prog. Horm Res. 2004; 59: 207-223.

24. Kivipelto M, Ngandu T, Fratiglioni L, Viitanen M, Kåreholt I, Winblad B, Helkala EL, Tuomilehto J, Soininen H, Nissinen A. Obesity and vascular risk factors at midlife and the risk of dementia and Alzheimer disease. Arch Neurol. 2005; 62(10): 1556-1560.

25. Fogelholm M, Malmberg J, Suni J, Santtila M, Kyrolainen H, Mantysaari M. Waist circumference and BMI are independently associated with the variation of cardio-respiratory and neuromuscular fitness in young adult men. Int J Obes. 2006; 30: 962-969. 